\title{
STUDIES ON SEED-SETTING IN LEGUMINOUS PLANTS. I. PEAS
}

\author{
Rolf Manner \\ Plant Breeding Institute Gullåker, Hammenhög, Sweden
}

Received April 28, 1958

The leguminous plants play a significant part in plant husbandry in Northern Europe. This is partly owing to the fact that they constitute the most important group of plants that can alternate with the grasses - the outstanding plant group in these countries. The leguminous plants therefore offer the largest possibility for making a suitable rotation of crops. Further, the leguminous plants are the best producers of proteins.

In this and a following paper the present author will deal with the seed-setting and, to some extent, the seed-growing problems in peas and vetches. These two are the most important leguminous crops in Northern Europe, with the exception of clover and lucerne.

The seed crops of peas vary to a very large extent, which has been explained as depending on the climate $(1,3,5,23,28,29)$, on the soil and the preceding crop (4), and on na notable percentage of poorly or non-developed seeds" (44). The large variation in the seed crops of peas in practical plant husbandry is of economical importance for both the private farmer and the entire countries. Naturally this uncertainty in the cultivating of these crops has negatively influenced the growing of these plants.

In Finland the cultivation of peas and the conditions for this cultivation are studied and given by Hänninen (12), Pesola (24), Pohjakallio and Salonen (25) and VALLE $(38,39)$.

Furthermore, it must be pointed out that the seed production of both vetches and late ripening peas is not large enough to satisfy the demand for them, which causes importation, especially of seed vetches to Finland, Norway and Sweden. The imported vetches are seldom of varieties with the highest possible cultivation value for these countries.

\section{Earlier investigations}

The seed yield of peas is according to inter alia HeYN (10), per hectare = number of plants $\times$ mean seed weight per plant. The mean seed weight per plant is 
a complex character consisting of the number of pods per plant, number of seeds per pod and mean seed weight.

Most of the characters investigated in the present study have been found to be heritable characters, namely, inter alia: length of stem $(2,13,15,22,43)$, length of internodes $(13,14,27,32,43)$, thickness of stem (14), breadth of pod (19), the number of flowers per peduncle and node $(30,37,40)$, the node number with the first flower $(2,11,14,30,32,40,41)$, seed weight $(36,40)$, length of pod $(20)$, breadth of pod $(17$, $18,19,20)$, number of ovules (34), node number $(40)$ and mean seed weight $(36,45)$.

HAAN (9) pointed out that "crossed seeds do not possess more vitality than selfed ones». LAMPRECHT (16) has extensively treated the sterility in peas and reviewed the relevant literature.

Wellensiek and Keyser (42) found a dominant gene Q, causing abortion of "some of the seeds in the pods". HaAN (9) found both autonomic and stimulative parthenocarpy in peas. Except the abortion of the seeds in the case of stimulative parthenocarpy, he found pods with reduced number of seeds, which he considered as "a result of abortion". TEDIN (31) found plants with aberrant seeds and rather commonly occurring failure in germinating capacity.

In Finland the seed-setting in peas was extensively investigated by TERÄsVUORI (34) in a larger and more comprehensive material than the present one. He found the number of ovules and number of seeds to be larger in under pods (earlier) than in over pods (later) and single pods. Of additional interest is the consideration made by TERVÄSVUORI that the seed number is much more dependent on environmental factors than the number of ovules.

WiKLUND (44) found a large percentage ( $0-47$ per cent) of the ovules to develop to "poorly or non-developed seeds" and further he considered that "a considerable percentage of pea ovules never get fertilized, as a mean 11 per cent for fodder pea and 20 per cent for yellow pea».

WUNDERLICH (46) got, as expected, a higher number of pods per plant and larger seed weight when the distance between the plants in the rows increased $(5-10-15$ centimetres).

The opening of the flowers follows successively upwards on the stem (26).

\section{Materials and methods}

The present study was conducted in the years $1956-58$ at Gullåkers Plant Breeding Institute, Hammenhög, Sweden, in connection with the practical plant breeding work there.

The material used for the present investigation was as follows:

I. Torsdags III, Brio, Svensk sabel, Parvus, Jo 0715, Carouby $\times$ Torsdags III $\left(\mathrm{F}_{2}\right)$, Brio $\times$ Svensk sabel $\left(\mathrm{F}_{2}\right)$, Parvus $\times$ Carouby $\left(\mathrm{F}_{2}\right)$, Torsdags III $\times$ Carouby $\left(\mathrm{F}_{2}\right)$, Svensk sabel $\times$ Brio $\left(\mathrm{F}_{1}\right)$, Svensk sabel $\times$ Parvus $\left(\mathrm{F}_{1}\right)$, Torsdags III $\times$ Parvus $\left(\mathrm{F}_{1}\right)$, Torsdags III $\times$ Brio $\left(\mathrm{F}_{1}\right), \mathrm{Hg} 55423 \times$ Parvus $\left(\mathrm{F}_{1}\right), \mathrm{Hg} 55423 \times$ Brio $\left(F_{1}\right), H g 55424 \times$ Brio $\left(F_{1}\right), H g 55424 \times$ Parvus $\left(F_{1}\right)$, Emigrant $\times$ Torsdags III $\left(F_{1}\right)$, Emigrant $\times$ Jo $0715\left(\mathrm{~F}_{1}\right)$, Mansholts $\times$ Torsdags III $\left(\mathrm{F}_{1}\right)$, Mansholts $\times$ Jo $0715\left(\mathrm{~F}_{1}\right)$, Viktoria (Dippe) $\times$ Torsdags III $\left(\mathrm{F}_{1}\right)$, Viktoria (Dippe) $\times$ Jo $0715\left(F_{1}\right)$, Viktoria (Mahndorfer) $\times$ Torsdags III $\left(F_{1}\right)$, Viktoria (Mahndorfer) 
$\times$ Jo $0715\left(\mathrm{~F}_{1}\right)$, and Brio $\times$ Parvus $\left(\mathrm{F}_{1}\right)$. Altogether 417 plants of this material were investigated as to inter alia the following characters:

1. Number of flowers per plant.

2. Number of developed pods per plant.

3. Percentage of non-developed pods.

4. Number of node with the lowest pod, on an average.

5. Number of node with the highest pod, on an average.

6. The pod-bearing part of the plant, measured in nodes.

7. Plant height in centimetres.

8. The pod frequency on different nodes.

9. The frequency of flowers not forming pods and fallen pods.

10. Mean number of seeds per plant.

11. Mean seed weight per plant.

12. Mean seed weight.

13. Mean thickness of the stalk.

14. Mean length of the pods.

15. Mean breadth of the pods.

16. Mean length of the internodes.

17. Mean seed weight of seeds with different position in the pod.

18. Pod-setting percentage.

19. Flower frequency on different node number.

20. Pod frequency on different node number.

II. Torsdags III $\times$ Brio $\left(\mathrm{F}_{1}\right)$ and $\mathrm{Hg} 55423 \times$ Parvus $\left(\mathrm{F}_{1}\right)$ : altogether 17 plants of these crosses were investigated inter alia as to the following characters:

21. Percentage and number of fully developed seeds.

22. Percentage and number of defective seeds.

23. Percentage and number of dead ovules.

24. Mean seed weight.

25. Pods with all seeds fully developed.

26. Length of pods, millimetres.

27. Breadth of pods, millimetres.

28. Number of ovules per ovary.

29. Length of peduncle.

30. Seed weight milligrams per pod.

Tables 1, 4 and 5 are based on the material of group I. The other tables are based on the material of group II.

With defective seeds are understood such as were considerably smaller than fully-developed. The seed weight of defective seeds has been estimated to be less than half the normal for fully developed seeds of the variety or the cross in question.

The $\chi^{2}$-values have been calculated in conformity with Finney (6) and the significance has been estimated in accordance with FISHER and YATES (7) and were denoted by asterisks: $* * *=\mathrm{P} \equiv 0.001$ (highly significant), ${ }^{* *}=\mathrm{P} \equiv 0.01$, but $>0.001$ (satisfactorily significant), and ${ }^{*}=\mathrm{P} \equiv 0.05$, but $>0.01$ (significant).

The maximum and minimum values in Table 1 are calculated on 10 plants from each plot.

Ovules that have not given rise to seeds have been mentioned as "dead ovules" or sometimes "non-developed seeds". The flowers that have not given rise to pods containing any seed at all are mentioned as mon-developed or fallen pods». This 
terminology is used because it is not quite clear what has happened with these flowers, ovaries or pods.

\section{Mean performance and breadth of variation}

The number of flowers per plant varied from 3.7 to 16.5. The corresponding extreme values for number of developed pods per plant were 3.7 and 14.9. The difference between number of flowers and number of pods sat is the part of flowers, which did not give rise to pod-development. This part of the flowers is given in Table 1 in percentage and varies in the present material between 0 and 16 , which are considerably smaller percentages than WIKLUND (44) found in the north of Sweden. In the present material the percentage in more than 400 investigated plants was 5.5 (Table 1).

Observations were undertaken as to the number of nodes with the lowest pod and the highest pod. Large variation was found. On an average, the first pod was found on the 5 th or 6 th node with variation from 3.1 to 8.6 . On an average, in the material investigated, the last pod was found on the 10th to 11th node with variation for the different varieties and crosses between 6.6 and 13.9. Further, in the table the part of the stem bearing pods is given in nodes. This part varies from 3.2 to 8.8 nodes for the different varieties and crosses. The mean value for the entire material was 6.0. The values of the pod-bearing part of the plants on an average seems to consist of about the same number of nodes as the non pod-bearing part of the stem lower than the first pod-bearing node, at least to some extent.

The number of internodes was on an average only a little larger than the number for the highest pod. The length of the internodes was on an average 11.7 centimetres and varied for the different varieties and crosses between 9.6 and 15.1 centimetres (Table 1).

Table 1. Mean performance and breadth of variation of the investigated characters in material I.

\section{Character}

\section{Minimum Mean Maximum}

Number of flowers per pod

Number of developed pods per plant

Percentage of non-developed pods

Number of node with the lowest pod

Number of node with the highest pod

The pod-bearing part of the plant, measured in nodes

Plant height in centimetres

Mean number of seeds per plant

Mean seed weight per plant, grams

Mean seed weight, milligrams

Mean thickness of the stem, millimetres

Mean length of the pods, millimetres

Mean breadth of the pods, millimetres

Mean length of the internodes, centimetres

$\begin{array}{ccc}3.7 & 10.2 & 16.5 \\ 3.7 & 9.6 & 14.9 \\ 0.0 & 5.5 & 16.0 \\ 3.1 & 5.7 & 8.6 \\ 6.6 & 10.8 & 13.9 \\ 3.2 & 6.0 & 8.8 \\ 95 & 129 & 165 \\ 22.9 & 54.1 & 85.7 \\ 8.23 & 16.26 & 26.59 \\ 231 & 303 & 414 \\ 4.7 & 5.8 & 6.9 \\ 58 & 67 & 78 \\ 11.4 & 13.0 & 15.7 \\ 9.6 & 11.7 & 15.1\end{array}$


Table 2. Development of first, central and last seeds in the pods.

\begin{tabular}{|c|c|c|c|c|c|c|c|}
\hline \multirow{2}{*}{$\begin{array}{c}\text { Position of } \\
\text { the seed }\end{array}$} & \multirow[b]{2}{*}{$\mathbf{n}$} & \multicolumn{2}{|c|}{ Fully developed } & \multicolumn{2}{|c|}{ Defective } & \multicolumn{2}{|c|}{ Dead ovules } \\
\hline & & Number & $\%$ & Number & $\%$ & Number & $\%$ \\
\hline First & 254 & 155 & 61.0 & 71 & 28.0 & 28 & 11.0 \\
\hline Central & 372 & 354 & 95.2 & 14 & 3.7 & 4 & 1.1 \\
\hline Last & 254 & 210 & 82.7 & 34 & 13.4 & 10 & 3.9 \\
\hline
\end{tabular}

Mean number of seeds per plant has been for the whole material 54.1, and varied between 22.9 and 85.7 for the different varieties and crosses. The corresponding mean seed weights per plant were $16.26,8.23$ and 26.59 , respectively. On an average the mean seed weight was 303 milligrams. The mean seed weight varied for the different varieties and crosses between 231 and 414 milligrams.

\section{Seed development in different parts of the pods of peas}

The present author considered it to be of interest to see to what extent the seedsetting in the pods showed dependence on the place for the ovules. 254 pods were consequently investigated. In the 118 cases the ovule and seed number, respectively, in the ovaries and pods, respectively, were even, both the central ovules or seeds being taken into consideration in Table 2 .

On an average the percentage of outermost ovules developing to seeds was much smaller than that of the central ovules. Of the first ovules in the ovaries only 61.0 per cent developed to seeds. The corresponding percentage for the last seeds was 82.7 , whereas 95.2 per cent of the central ovules developed to seeds. Th i s $\mathrm{s} \mathrm{h} \mathrm{ow} \mathrm{s}$ clearly that the percentage of fully developed seeds is larger in the central part of the pod than in the ends of the pods $\left(x^{2}=140.2^{* * *}\right)$. The percentage of developed seeds was larger for the last ovule than for the first $\left(x^{2}=38.6\right)^{* * *}$. The difference between central and last seed showed much smaller significance $\left(\chi^{2}=4.8^{*}\right)$. Of the first ovules in the ovaries, 28.0 per cent were defective and 11.0 per cent not at all developed. The corresponding percentages for central ovules were 3.7 and 1.1, respectively, and for the last ovules in the ovaries 13.4 and 3.9 , respectively. Thus of the ovules not grown to fully developed seeds about one fourth part was not at all developed. This percentage didnot seem to beinfluenced by the position of the ovule in the ovary.

It is further of interest to see to what extent the seed weight is dependent on the location of the developed seed in the pod. A material consisting of 117 pods was investigated. The pods were grouped after number of seeds per pod. In all the groups the first and last seeds were on an average smaller than the seed in the central part of the pod. The differences in weight were about ten per cent between the outermost seeds and the central ones. 
In the above-mentioned investigation was found an indication that the mean seed weight of the seeds should be somewhat larger in pods with many seeds per pod than pods with a smaller seed number per pod. A further indication of the dependence of seed-setting on the number of ovules in the pod is given in Table 3. Here we see the number and percentage of pods containing defective seeds and non-developed ovules, respectively. Further, the number and percentage of pods containing both defective seeds and non-developed ovules is given. In the two last columns of the table are given the number and percentage of pods with all their seeds fully developed.

From Table 3 it clearly appears that the percentage of pods containing only fully developed seedsincreases with an increasing number of ovules per flower, which must be considered of great interest.

The percentage of pods containing defective seeds but no non-developed ovules is rather constant and seems not to vary with the number of ovules per ovary, whereas the percentage of pods containing dead ovules seems to decrease with an increasing number of ovules per ovary, if the small material containing four ovules per ovary is excepted. The percentage of pods with both defective seeds and dead ovules point in the same direction, which must be considered as very interesting.

In Table 2 it was shown that the defective seeds and dead ovules are usually found at the ends of the pods, and in Table 3 we see that the largest percentage of pods with all seeds fully developed is for pods with a large number of seeds per pod.

Table 2 points clearly to the fact that the largest frequencies of defective seeds and dead ovules were at the ends of the pods. Below it is clearly shown for the present material that the percentage of defective seeds and dead ovules is largely dependent on the number of ovules per ovary:

\begin{tabular}{|c|c|c|c|c|c|}
\hline \multirow{2}{*}{$\begin{array}{c}\text { Number of ovules } \\
\text { per ovary }\end{array}$} & \multirow[b]{2}{*}{$\mathrm{n}$} & \multicolumn{2}{|c|}{ Defective seeds } & \multicolumn{2}{|c|}{ Dead ovules } \\
\hline & & number & $\%$ & number & $\%$ \\
\hline 4 & 28 & 8 & 28.6 & 5 & 17.9 \\
\hline 5 & 160 & 23 & 14.4 & 11 & 6.9 \\
\hline 6 & 408 & 38 & 9.3 & 26 & 6.4 \\
\hline 7 & 728 & 66 & 9.1 & 12 & 1.6 \\
\hline 8 & 344 & 30 & 8.7 & 1 & 0.3 \\
\hline
\end{tabular}

\section{Pod-setting and its dependence on node number}

The present author considered it to be of interest to see whether differences could be found for flowers with different node numbers. The investigated number of flowers and pods, respectively, is given in Table 4. Further, in this table the pod-setting 
percentage is given on different node numbers. In the table is found a rather clear tendency to decreasing pod-setting percentage with increasing node number or increasing height for the pod on the stem.

The above-mentioned tendency is further reported by the numerical material in Table 5, where the numbers and pod-setting percentages are given for 417 investig-

Table 3. Number of pods containing defective seeds or dead ovules .

\begin{tabular}{|c|c|c|c|c|c|c|c|c|}
\hline \multirow{2}{*}{$\begin{array}{l}\text { Number } \\
\text { of ovules } \\
\text { per ovary }\end{array}$} & \multicolumn{2}{|c|}{ Defective seeds } & \multicolumn{2}{|c|}{ Dead ovules } & \multicolumn{2}{|c|}{$\begin{array}{c}\text { Defective seeds } \\
\text { and dead ovules }\end{array}$} & \multicolumn{2}{|c|}{$\begin{array}{c}\text { Pods with all seeds } \\
\text { fully developed }\end{array}$} \\
\hline & Number & $\%$ & Number & $\%$ & Number & $\%$ & Number & $\%$ \\
\hline 4 & 3 & 43 & - & - & 3 & 43 & 1 & 14 \\
\hline 5 & 11 & 34 & 5 & 16 & 4 & 13 & 12 & 38 \\
\hline 6 & 21 & 31 & 11 & 16 & 8 & 12 & 28 & 41 \\
\hline 7 & 41 & 39 & 5 & 5 & 5 & 5 & 53 & 51 \\
\hline 8 & 16 & 37 & - & - & 1 & 2 & 26 & 60 \\
\hline
\end{tabular}

Table 4. Pod-setting percentage.

\begin{tabular}{rrrr}
\hline $\begin{array}{c}\text { Node } \\
\text { number }\end{array}$ & $\begin{array}{c}\text { Number } \\
\text { of flowers }\end{array}$ & $\begin{array}{c}\text { Number } \\
\text { of pods }\end{array}$ & $\begin{array}{c}\text { Pod-setting } \\
\text { percentage }\end{array}$ \\
\hline 3 & 60 & 59 & 98 \\
5 & 171 & 166 & 97 \\
6 & 353 & 339 & 96 \\
7 & 516 & 490 & 95 \\
8 & 586 & 567 & 97 \\
9 & 590 & 559 & 95 \\
10 & 550 & 513 & 93 \\
11 & 462 & 438 & 95 \\
12 & 277 & 384 & 93 \\
13 & 153 & 248 & 90 \\
14 & 87 & 143 & 93 \\
15 & 46 & 78 & 90 \\
16 & 18 & 40 & 87
\end{tabular}

Table 5. Pod-setting percentage on the two lowest and the two highest fertile nodes.

\begin{tabular}{lcccc}
\hline Node & $\begin{array}{c}\text { Number of } \\
\text { investigated plants } \\
\text { flowers }\end{array}$ & $\begin{array}{c}\text { Number of } \\
\text { pods }\end{array}$ & $\begin{array}{c}\text { Pod-setting } \\
\text { percentage }\end{array}$ \\
\hline First & 417 & 716 & 693 & 97 \\
Second & 417 & 716 & 685 & 96 \\
Next last & 417 & 679 & 622 & 92 \\
Last & 417 & 693 & 534 & 89
\end{tabular}


Table 6. The pod length, pod breadth, number of ovules, number of seeds, length of peduncle, seed weigth per pod and their dependence on the position on the stem.

\begin{tabular}{|c|c|c|c|c|c|c|c|c|}
\hline $\begin{array}{l}\text { Position } \\
\text { of the } \\
\text { pod }\end{array}$ & $\begin{array}{l}\text { The length } \\
\text { of the } \\
\text { pods, milli- } \\
\text { metres }\end{array}$ & $\begin{array}{l}\text { The breadth } \\
\text { of the } \\
\text { pods, milli- } \\
\text { metres }\end{array}$ & $\begin{array}{c}\text { Number of } \\
\text { ovules } \\
\text { per ovary }\end{array}$ & $\begin{array}{l}\text { Number of } \\
\text { fully deve- } \\
\text { loped seeds }\end{array}$ & $\begin{array}{l}\text { Number of } \\
\text { defective } \\
\text { seeds }\end{array}$ & $\begin{array}{c}\text { Number of } \\
\text { dead } \\
\text { ovules }\end{array}$ & $\begin{array}{l}\text { Length of } \\
\text { peduncle, } \\
\text { milli- } \\
\text { metres }\end{array}$ & $\begin{array}{c}\text { Seed } \\
\text { weight, } \\
\text { milligrams } \\
\text { per pod }\end{array}$ \\
\hline
\end{tabular}

$\begin{array}{lllllllll}\text { First } & 64 & 11.5 & 6.5 & 5.7 & 0.6 & 0.2 & 101 & 1648 \\ \text { Second } & 65 & 11.5 & 6.8 & 6.1 & 0.4 & 0.3 & 84 & 1796 \\ \text { Third } & 66 & 11.9 & 7.0 & 6.3 & 0.6 & 0.1 & 81 & 1728 \\ & & & & & & & & \\ \text { Central } & 63 & 11.4 & 6.5 & 5.6 & 0.6 & 0.3 & 88 & 1610 \\ & & & & & & & & \\ \text { The next } & 65 & 11.4 & 6.5 & 5.5 & 0.8 & 0.2 & 78 & 1520 \\ \text { Next last } & 63 & 11.0 & 6.4 & 5.7 & 0.5 & 0.2 & 75 & 1574 \\ \text { Last } & 63 & 11.2 & 6.6 & 5.5 & 0.6 & 0.5 & 62 & 1469\end{array}$

ated plants. This table shows clearly that the first and second flowers have on an average, shown clearly higher pod-setting percentage than the two last (highest) ones. The statistical significance was well established $\left(\chi^{2}=22.9^{* * *}\right)$.

\section{Seed-setting and its dependence on the position of the pod}

In Table 6 the mean values are given for some investigated characters and their dependence on the position of the pod. As first, second and third pods, respectively, are taken the first, second and third pods from the soil. As last pod, is taken the one with the highest position - measured in nodes - on the stem.

The number of ovules per ovary has not shown any considerable dependence on the position of the pods on the stem. A small tendency to higher numbers of ovules in the second and third flower than in the other flowers is found, but this tendency is not significant. The number of fully developed seeds showed about the same variation.

It was interesting to find that the peduncle length on an average decreases with an increasing node number for the node on which the pod is developed (Table 6). The only exception was the peduncle length for the "centrals pod. Earlier TediN and WiTT (33) found the length of the peduncles to decrease with increasing height for the peduncles on the plant.

In the last column in Table 6 the seed weight is given in milligrams per pod. From these numbers it appears that the three last pods have had much smaller seed weights per pod than the three first pods. The central pods had intermediate weights. The differences were considerable. Further, it must be considered as interesting that the first pod has on an average had smaller seed weight than the second and third 
Table 7. Comparison between nodes with different number of pods and different pod position

\begin{tabular}{|c|c|c|c|c|c|c|c|c|c|}
\hline $\begin{array}{c}\text { Position } \\
\text { of the node } \\
\text { and pod number } \\
\text { and pod position }\end{array}$ & $\mathrm{n}$ & $\begin{array}{c}\text { The length } \\
\text { of the } \\
\text { pods, } \\
\text { milli- } \\
\text { metres }\end{array}$ & $\begin{array}{l}\text { The brea- } \\
\text { dth of the } \\
\text { pods, } \\
\text { milli- } \\
\text { metres }\end{array}$ & $\begin{array}{l}\text { Number } \\
\text { of ovules } \\
\text { per } \\
\text { ovary }\end{array}$ & $\begin{array}{l}\text { Number } \\
\text { of fully } \\
\text { developed } \\
\text { seeds }\end{array}$ & $\begin{array}{l}\text { Number } \\
\text { of } \\
\text { defective } \\
\text { seeds }\end{array}$ & $\begin{array}{c}\text { Number } \\
\text { of } \\
\text { dead } \\
\text { ovules }\end{array}$ & $\begin{array}{l}\text { Length } \\
\text { of pe- } \\
\text { duncle, } \\
\text { milli- } \\
\text { metres }\end{array}$ & $\begin{array}{c}\text { Seed } \\
\text { weight, } \\
\text { milli- } \\
\text { grams } \\
\text { per pod }\end{array}$ \\
\hline \multicolumn{10}{|l|}{ One pod per node } \\
\hline Lowest & 5 & 68 & 11.8 & 7.0 & 6.6 & 0.2 & 0.2 & 115 & 2084 \\
\hline Central & 5 & 64 & 11.2 & 7.0 & 6.6 & - & 0.4 & 80 & 1886 \\
\hline Highest & 9 & 62 & 11.2 & 6.6 & 5.3 & 0.6 & 0.7 & 62 & 1374 \\
\hline Mean & & 64 & 11.4 & 6.8 & 6.0 & 0.3 & 0.5 & 81 & 1696 \\
\hline \multicolumn{10}{|l|}{ Two pods per node } \\
\hline Lowest & 32 & 67 & 11.6 & 6.8 & 6.4 & 0.3 & 0.1 & 112 & 1912 \\
\hline Central & 78 & 69 & 11.6 & 7.1 & 6.3 & 0.7 & 0.1 & 97 & 1794 \\
\hline Highest & 32 & 64 & 11.3 & 6.5 & 5.6 & 0.7 & 0.2 & 74 & 1534 \\
\hline Mean & & 67 & 11.5 & 6.9 & 6.2 & 0.6 & 0.2 & 95 & 1762 \\
\hline \multicolumn{10}{|l|}{ Three pods per nod } \\
\hline Mean & 14 & -57 & 11.0 & 6.3 & 5.2 & 0.8 & 0.3 & 66 & 1387 \\
\hline \multicolumn{10}{|c|}{ Four pods per node } \\
\hline Mean & 24 & 66 & 11.3 & 6.5 & 5.2 & 1.1 & 0.2 & 83 & 1327 \\
\hline \multicolumn{10}{|l|}{ Five pods per node } \\
\hline Mean & 15 & 61 & 11.0 & 6.2 & 5.3 & 0.8 & 0.1 & 66 & 1231 \\
\hline \multicolumn{10}{|l|}{ Six pods per node } \\
\hline Mean & 35 & 61 & 11.1 & 6.6 & 5.5 & 0.6 & 0.5 & 67 & 1315 \\
\hline \multicolumn{10}{|c|}{ Seven pods per node } \\
\hline Mean & 22 & 61 & 11.4 & 6.5 & 5.5 & 0.8 & 0.2 & 73 & 1369 \\
\hline \multicolumn{10}{|c|}{ Podposition } \\
\hline Over pod & 109 & 64 & 11.3 & 6.7 & 5.7 & 0.8 & 0.2 & 100 & 1.526 \\
\hline Under pod & 105 & 66 & 11.5 & 6.9 & 6.0 & 0.6 & 0.3 & 78 & 1.653 \\
\hline , Single & 48 & 61 & 11.2 & 6.4 & 5.6 & 0.5 & 0.3 & 66 & 1.514 \\
\hline
\end{tabular}

pod. The numerical material in Table 6 indicates a tendency for the mean seed weight to be somewhat smaller for the three highest pods on an average than for the three lowest pods on the stem.

\section{The influence of pod number per node}

In Table 7 the numerical material is given for comparisons between different number of pods per node and some characters which were given in Table 6. Only as regards the nodes with one and two pods, respectively, was it possible to group the nodes in accordance with their position on the stem. For the nodes with more than two pods per node the material was rather small.

The length of the pods showed a tendency to be larger on an average at nodes with two pods per node than at nodes with $3,5,6$ and 7 pods per node. The breadth of the pods was on an average largest for pods from nodes with two pods. 
Number of ovules per ovary showed a tendency to be higher for flowers from nodes with one or two flowers per node than for flowers from nodes with a larger flower number. The higher means for flowers from nodes with one or two flowers per node seem to depend entirely on the flowers from the lowest and the central flower-bearing nodes, which is in full conformity with the numerical material in Table 6. The same tendency - but here the differences are much clearer -- is found for the results for number of fully developed seeds. Thus the number of fully developed seeds per pod is considerably larger for pods from nodes with only one or two pods than for pods from nodes with three or more pods per node.

The number of defective seeds and dead ovules was smallest for pods from nodes with two pods per node or on an average 0.7 . The corresponding number for pods from nodes with only one pod per node was 0.8 , and, for pods from nodes with three pods per node or more, varied between 0.9 and 1.3 per pod. Because the pods from nodes with two pods per node had the largest number of ovules per flower the differences in percentage will be rather large.

Seed weight per pod has been much larger for pods from nodes with one or two pods per node than for pods developed on nodes with three or more pods per node. The difference was twenty per cent or more. On an average the pods from nodes with two pods per node had higher seed weight per pod than pods from nodes with only one pod on each node.

In Table 7 the differences in seed weight per pod between the lowest and the highest pod appears very clearly, which has been earlier discussed in connection with Table 6.

\section{Comparison between under and over pods}

In Table 7 the numerical values are given in regard to the same characters as used in Tables 6 for over and under pods. The corresponding values are also given for a third group, single. In this group are brought together the pods found to be only one on each peduncle.

Both the length and the breadth of the pods were largest for the under pods, smaller for the over pods and smallest for the single pods. The differences were larger as to the length than as to the breadth of the pods. This is in conformity with the results given in Table 7 .

Also the number of ovules per flower and the number of fully developed seeds per pod were largest for under pods and smallest for the single pods. The number of defective seeds was highest for the over pods. The differences with regard to the dead ovules were unimportant.

The seed weight per pod was considerably larger for under pods than for over and single pods.

Both the somewhat higher number of seeds per pod and seed weight per pod found in the present investigation agree with the results obtained by Gross (8), but the differences in his investigation were much larger in most cases. He found differences between different varieties. 


\section{Discussion}

Between 1.1 and 11.0 per cent of the ovules in the pods do not seem to develop at all. These percentages are considerably smaller than those found by WIKLUND (44) in the north of Sweden. For the first ovule in the pod these percentage was much higher than for the central ones. It has not been possible for the present author to decide whether this group of ovules has or has not been fertilized, which WikLund considers to be the case in his material. Possibly his conception is correct, but the present author must give two points of view pointing in an other direction, namely, that the first ovules show the largest percentage dead ovules. To the present author the end ovules seem to have had the same possibilities as the central ovules in the flowers to get fertilized. The second view, pointing in the same direction in the present material, refers to the dead part (one fourth) of the ovules not developed to seeds that seemed to be independent of the location of the ovules. Both these phenomena suggest that the most important factors should have been the nutritional, water and climatic conditions, mentioned by WIKLUND, and possibly to the time fact or and the rhythm of development, which factors possibly are only of secondary influence. The results given in Tables 3 point in the same direction.

The defective pod- and seed-setting in the present material must thus be considered to be at least partly depending on environment. If defectiveness in pod- and seed-setting is caused by internal causes [Innere Ursachen (16)] in the present material it must be considered to be caused by indirect genetical causes (Indirekte Genwirkung). The defectiveness in pod- and seed-setting found in the present material must be considered to have nothing to do with sterility caused by plasmatic, chromosomal and direct genetical causes (Plasmatische Ursachen, Chromosomale Ursachen and Direkte Genwirkung (16)].

In oil flax the present author (21) found dependence between the length of the branch and seed-setting and seed yield, respectively. No such dependence was found in the present material of peas. The cause of this seems to be the fact that the peduncle length decreases with increasing height, measured with nodes, for the pod; and the later time for flowering also plays its part. The higher on the stem the position of the flower, the later the flower has developed and the development of pod has begun. A connection between flowering time and seed weight per pod must be considered to exist in the case of peas too, because the opening of the flowers proceeds from the lower nodes to the higher ones (26) and the seed weight per pod decreases with increasing height for the pods on the stem (Table 6). From the same table it appears that with decreasing peduncle length the seed weight per pod decreases. This does not seem to be in agreement with the results of the above-mentioned oil flax investigation. But on closer reflection it appears that in oil flax the branches develop from a rather small section of the stem, but in peas the differences in height on the stem for the different peduncles are large. Therefore the present author considers that the correlation between length of the whole conducting tissues to the pods in peas and the capsules in oil flax, on the one hand, and the seed weight per pod, on the other, will be to some extent negative. In agreement with this are the results of the comparison between over and under pods which are all in pairs (Table 7). 
The stem length is the same for both but the peduncle length is much longer for the over pods and the over pods have on an average a considerably smaller seed weight per pod. Thus, on the whole, it can be said that the results of seed-setting studies in oil flax and peas agree with each other very well. This is especially true of decreasing pod- and capsule-setting, respectively, and seed weight per pod and capsule, respectively, with increasing length of the conducting tissues to the flowers and pods and later flower development and flowering.

On the basis of the present material (Tables 2 and 3 ) it seems possible that peas with a large number of seeds per pod should give a seed crop that is more even in seed development, which can be of importance in the production of assorted peas as is the case with seeds for sowing and eating. This naturally depends on to what extent the differences in the present material are genetical and to what extent it is valid for different material.

On the whole the pod length, pod breadth, number of ovules and number of seeds seem to some extent to follow each other (Tables 6 and 7 ).

The differences in seed number (fully developed seeds) between over, under and single pods indicated in Table 7 agree well with the results obtained by other investigators (34).

\section{$S u m m a r y$}

The differences between different genetical materials with regard to the investigated characters have been large.

The percentage of fully developed seeds has been smallest for the first seed in the pods on an average (61.0) and much larger for the central seeds (95.2).* The corresponding percentage for the last (outermost) seed in each pod was intermediate (82.7).

Of the not fully developed seeds, about a fourth part was not at all developed and classified as dead ovules. The relations between the two groups, defective seeds and dead ovules, showed no influence on the position of the seed in the pod.

The percentage of pods with all seeds fully developed varied between 14 and 60 , and was much dependent on the number of ovules per ovary.

The percentage of pod-setting was higher for the low nodes than for the higher ones.

The number of ovules per ovary and number of fully developed seeds per pod showed a small tendency to be higher for the lower pods on the stem than for the pods with a high position on the stem.

Peduncle length was clearly higher for the lower pods than for the pods with a high position on the stem.

Seed weight per pod was considerably higher for pods with a low position on the stem (early flowering) than for pods with a high position on the stem (late flowering).

The length and breadth of the pods, number of ovules per ovary and number of fully developed seeds per pod have on an average been larger for pods from nodes 
with only one or two pods per node than for pods from nodes with three or more pods per node.

The peduncle length was on an average higher for pods on nodes with two pods per node than for pods from nodes with only one pod per node or if the pod number per node was three or even higher.

The seed weight per pod was on an average highest for pods developed from nodes with two pods per node and much smaller for pods developed from nodes with three or more pods per node. The seed weight per pod was intermediate for the pods springing from nodes with only one pod.

The length of the pods, the breadth of the pods, number of ovules per ovary and number of fully developed seeds were higher for under pods than for over pods. The corresponding numbers for the single pods were lower than for both over and under pods.

The peduncle length was considerably smaller for single pods than for over and under pods in the investigated material.

Seed weight per pod was higher for under pods than for over pods and single pods.

\section{R E F E R E N C E S}

(1) BAchér, I. 1949. Blandsăd av havre och ärt (With Engl. summary). Lantbrukshögsk. jordbr. förs.anst., Medd. 28: $1-80$.

(2) Bateson, W. \& Killby, M. 1905. Experimental studies in the physiology of heredity. Peas (Pisum sativum). Roy. Soc. Rep. to the Evol. Committee 2: 55-80.

(3) Brouwer, W. 1926. Die Beziehungen zwischen Ernte und Witterung in der Landwirtschaft. Landw. Jahrbücher 63: 1-81.

(4) Elıssson, S. \& Jacobson, G. 1946. Sortförsök med ärter och baljväxtblandsäd (With Engl. summary). Lantbrukshögsk., jordbr.förs.anst. Medd. 17: 1-108.

(5) Ericsson, G. \& Genchel, M. 1947. Försök med ärter och ärtblandsäd vid Statens Försöksgård Offer âren 1935-1946 (With Engl. summary). Ibid. Medd. 21: 1-67.

(6) FINNEY, D. J. 1953. An introduction to statistical science in agriculture. 179 pp. Copenhagen.

(7) Fisher, R. A. \& YATES, F. 1953. Statistical tables for biological, agricultural and medical research. 126 pp. Edinburgh.

(8) Gross, E. 1906. Uber die Ertragsfähigkeit von Erbsenpflanzen mit ein- und doppelhülsigen Fruchtständen. Oesterr. = Ungarische Z. Zuckerind. und Landw. 35: 78 -88.

(9) HaAn, H. de 1930. Contributions to the genetics of Pisum. Genetica 12: 321-439.

(10) Heyn, H. 1939. Speiseerbsen, Pisum sativum L. Handb. der Pfl.zücht. 3: 1-25. Berlin.

(11) Hoshino, Y. 1915. On the inheritance of the flowering-time in peas and rice. J. Coll. Agr. Tohoku Imp. Univ. Sapporo 6: 229-288.

(12) Hänninen, P. 1956. Herneen ja virnan viljelymahdollisuuksista kaurakasvustoissa Suomessa. Valt. maatal.koetoim. julk. N:o 153: 1-131.

(13) KAPPERT, H. 1920. Uber das Vorkommen vollkommener Dominanz bei einem quantitativen Merkmal. Z. Ind. Abst. u. Vererbungslehre 22: 199-209.

(14) Keeble, F. \& Pellew, C. 1910. The mode of inheritance of stature and of time of flowering in peas (Pisum sativum). J. Genet. 1: 47-56.

(15) LАмм, R: 1937. Length factors in dwarf peas. Hereditas 23: $38-48$.

(16) Lamprecht, H. 1951. Uber partielle und Semisterilität, insbesondere bei Pisum sativum. Z. Pflanzenzücht. 30: $422-433$.

(17) —- 1953. Ein Gen für schmale Hülsen bei Pisum und seine Koppelung. Agri Hort. Genet. 11: $15-27$. 
(18) $\longrightarrow$ 1954. Weitere Studien über die Vererbung der Hülsenbreite bei Pisum. Ibid. 12: $202-210$.

(19) — 1957. Uber die Vererbung der Hülsenbreite bei Pisum. Ibid. 15: 105-114.

(20) Lock, R. H. 1905. Studies in plant breeding in the tropics II. Ann. Roy. Bot. Gard. Peradeniya 2: 357-414. (Ref. White O. E. 1918).

(21) Manner, R. 1956. Studies on seed-setting and seed yield in oil flax. Diss. 139 pp. Hammenhög.

(22) Mendel, G. 1866. Versuche über Pflanzen-Hybriden. Facsimile-Ed. 1917, 47 pp. Berlin.

(23) Pedersen, A. 1950. Lærebog i Landbrugets Plantekultur II. 2. Udgave. 522 pp. København.

(24) Pesol., V. A. 1939. Tuleentuneena korjattavan hernekauran viljelyksestä. Maa 24: 14 -19.

(25) Pohjakallio, O. \& Salonen, A. 1948. Uber den Einfluss von Erbse auf die Trockensubstanzerzeugung von Hafer in Erbse-Hafer-Mischbestand. Maatal.tiet. aikak. 20: 143-156.

(26) Prjanischnikow, D. N. 1930. Spezieller Pflanzenbau. 719 pp. Berlin.

(27) Rasmusson, J. 1927. Genetically changed linkage values in Pisum. Hereditas 10: 1-152.

(28) RÜther, H. 1953. Grundlagen des Leguminoren-Anbaues-in Mitteldeutschland. Z.f. Acker- u. Pflanzenbau 96: 45-74.

(29) ТАмм, E. 1952. Uber Beziehungen zwischen Witterungsverlauf und Ertragsleistung bei landwirtschaftlichen Kulturpflanzen im ehemaligen Regierungsbezirk Potsdam. Ibid. 94: 166-189.

(30) TEDIN, H. 1897. Några synpunkter vid förädling af ärter. Sver. utsädesför. tidskr. 7: $111-129$.

(31) $\rightarrow$ 1920. The inheritance of flower colour in Pisum. Hereditas 1: 68 -97.

(32) $\rightarrow$ \& TEDIN, O. 1923. Contributions to the genetics of Pisum. III: Internode length, stem thickness and place of the first flower. Ibid. 4: $351-362$.

(33) —— \& Wiтr, H. 1899. Botanisk-kemisk undersökning af 42 nästan uteslutande nya ärtformer, uppdragna vid Sveriges Utsädesförening på Svalöf. Sver. utsädesför. tidskr. 9: 121-169.

(34) TERÄSvUORI, K. 1915: Ubber in Finnland feldmässig gebaute Erbsenformen. Acta Societatis Pro Fauna et Flora Fennica 40 (9): 1-142. Diss. Helsinki.

(35) Tschermak, E. von 1902. Ueber die gesetzmässige Gestaltungsweise der Mischlinge. Z. Landw. Vers.w. Oesterr. 5: 781-861.

(36) —- 1912. Bastardierungsversuche an Levkojen, Erbsen und Bohnen mit Rücksicht auf die Faktorenlehre. Z. ind. Abst. u. Vererbungsl. 7: 81-234.

(37) $\rightarrow$ 1919. Uber Züchtung landwirtschaftlich und gärtnerisch wichtiger Hülsenfrüchte. Arb. D.L.G. Oesterr. 1919: 80-106.

(38) VAlle, O. 1946. Tutkimuksia rehupalkokasveillamme. Hankkijan siemenjulkaisu 1946: 162 -175.

(39) —- 1946. Palkokasvien merkitys rehuviljan tuotannossa. Maatal. ja koetoim. 1. 20 pp.

(40) Wellensiek, S. J. 1925. Genetic monograph on Pisum. Bibliogr. Genet. 2: 343-473.

(41) —- 1925. Pisum-crosses. I. Genetica 7: 1-64.

(42) $\longrightarrow$ \& Keyser, J. S. 1929. Pisum-crosses. V. Inherited abortion and its linkage-relations, Ibid. 11: $329-334$.

(43) Whiте, O. E. 1918. Inheritance studies i Pisum. III. The inheritance of height in peas. Proc. of the Semicentennial anniversary of the Torrey Bot. Club. 17: $316-322$.

(44) Wiklund, K. 1954. Frösättning hos fältodlade ärter, Pisum sativum (L.) sens. ampl. Govorov (With Engl. summary). Sver. utsädesför. tidskr. 64: 211-219.

(45) Wringe, Ö. 1936. Linkage in Pisum. Comptes Rendus Lab. Carlsberg, Sér. Phys. $21: 271-393$.

(46) Wunderlich, G. 1953. Ertragsanalytische Untersuchungen an vier Erbsensorten bei verschiedener Bestandesdichte. Sonderdruck aus Die Bodenkultur» 7. Jahrg. Heft 1. 10 pp.

\section{SELOST U S :}

\section{PALKOKASVIEN SIEMENTEN MUODOSTUMISESTA. I. HERNE}

\section{Rolf Manner}

\section{Gullåkerin kasvinjalostuslaitos, Hammenhög, Ruotsi}

Vuosina $1956-57$ on tekijä Gullåkerin kasvinjalostuslaitoksella suorittanut joukon herneen siementen muodostumista koskevia tutkimuksia. Kasviaineistona on käytetty eräiden risteytyspopulaatioiden $\mathrm{F}_{1}$ - ja $\mathrm{F}_{2}$-sukupolvea ja muutamia näiden risteytyspopulaatioiden vanhempia. 
Tutkimustuloksista käy mm. selville, että käytetyssä aineistossa on vain $61.0 \%$ sikiäimien ensimmäisistä siemenaiheista kehittynyt täysikokoisiksi siemeniksi. Vastaavat prosenttiluvut sikiäimien keskimăisen ja viimeisen siemenaiheen suhteen olivat 95.2 ja 82.7 . Keskimäärin 5.5 prosenttia kaikista sikiäimistä ei kehittynyt ollenkaan tai ne kuolivat. Tämä prosenttimäärä oli suurempi kasvin latvassa kuin alempana varrella sijaitsevissa kukissa. Siementen keskipaino oli pienempi niillä siemenillä, jotka sijaitsivat palkojen päissä kuin siemenillä, jotka sijaitsivat palkojen keskiosissa. Yleensä oli siementen muodostuminen runsaampaa sikiäimissä, joissa oli paljon siemenaiheita, kuin sikiäimissä, joiden siemenaiheiden lukumäärä oli pieni. Siementen keskimääräinen paino oli pienempi kasvin latvassa olevissa kuin muissa paloissa ja suurempi parittain kuin yksitellen kasvavissa paloissa. 